\title{
3. MIDDLE FAN INTRODUCTION AND SUMMARY ${ }^{1}$
}

\author{
Shipboard Scientific Party ${ }^{2}$
}

\section{INTRODUCTION}

The middle fan area of the Quaternary Mississippi Fan is generally located between water depths of 1800 $\mathrm{m}$, where the break in slope occurs, and about 3000 to $3100 \mathrm{~m}$, where the position of the single central channel changes into a channel-switching mode with only one channel being active at any given time (Fig. 1).

Whereas the upper fan is basically a conduit system with minor overall aggradational characteristics, the middle fan is an active aggradational area. It is lenticular in cross section and is characterized by a channel-levee complex with adjacent lateral overbank deposits. The morphologically visible channel is highly sinuous in nature, asymmetrical in profile, and bounded by levees that are 10 to $20 \mathrm{~m}$ above the surrounding seafloor. Downfan the channel becomes less sinuous and its dimensions decrease. Near the drill sites the present open channel is 1.5 to $2.5 \mathrm{~km}$ wide and 40 to $45 \mathrm{~m}$ deep. During periods of active sediment transport, the actual channel depth likely was at least two to three times the present depth, based on the fine-grained nature of the upper part of the channel fill.

Analyses of GLORIA, Sea MARC and EDO sidescan sonar images show a large variety of features within the general area of the drill sites (Fig. 2). A combination of these sonar images with shallow and medium

\footnotetext{
${ }^{1}$ Bouma, A. H., Coleman, J. M., Meyer, A. W., et al., Init. Repts. DSDP, 96: Washington (U.S. Govt. Printing Office).

2 Addresses: Arnold H. Bouma (Co-Chief Scientist), Gulf Research and Development Company, P.O. Box 37048, Houston, TX 77236, (present address: Chevron Oil Field Research Company, P.O. Box 36506, Houston, TX 77236); James M. Coleman (Co-Chief Scien tist), Coastal Studies Institute, Louisiana State University, Baton Rouge, LA 70803; Audre W. Meyer (Shipboard Science Representative), Deep Sea Drilling Project, Seripps Institutio of Oceanography, La Jolla, CA 92093, (present address: Ocean Drilling Program, 500 University Drive West, Texas A\&M University, College Station, TX 77843); James Brooks, Department of Oceanography, Texas A\&M University, College Station, TX 77843; William R. Bryant, Department of Oceanography, Texas A\&M University, College Station, TX 77843; Richard Constans, Paleontology Section, Chevron US.A. Inc. 935 Gravier Street, New Orleas. LA 70112. Michel Cremer, Département de Ǵologie et Oofanographie, Universite de Bordeaux l, Avenue des Facultis, 33405 Talence Cedex, France; Laurence I. Droz, Labora Géodyname Sous Gesear Research Institute, University of Tokyo, Tokyo 164, Japan; Mahlon C. Kennicutt II, Department of Oceanography, Texas A\&M University, College Station, TX 77843; Barry Kohl, Chev ron U.S.A. Inc., 935 Gravier Street, New Orleans, LA 70112; william R. Normark, Pacifi Branch of Marine Geology, U.S. Geological Survey (MS-999), 345 Middlefield Road, Menlo Park, CA 94025: Suzanne O'Connell, Lamont-Doherty Geological Observatory of Columbia University, Palisades, NY 10964, (present address: Ocean Drilling Program, 500 University Drive West, Texas A\&M University, College Station, TX 77843); Mary Parker, Department of Geology, Forida State University, Tallahassee, FL 32306 , (present address: AMOCO Produc tion Company, P.O. Box 50879, New Orleans, LA 70150); Ken T. Picks: AMOCO Production Comertment of Earth Sciences, University of London, Goldsmith's College, London SE14 6NW, United Kingdom, (present address: Department of Geology, University of Leicester, Leicester LEI 7RH, United Kingdom); Claudia Schroeder, Department of Geology, Dalhousie University, Halifax, Nova Scotia B3H 3J5, Canada; Charles E. Stelting, Gulf Research and Development Company, P.O. Box 37048, Houston, TX 77236, (present address: Chevron Oil Field Re search Company, P.O. Box 36506 , Houston, TX 77236): Dorrik A. V. Stow, University of Ed inburgh, Edinburgh EH9 3JW, Scotland, United Kingdom, (present address: Oeology partment, University of Nottingham, Nottingham NG7 2RD, United Kingdom): Will DeSweet, Mineral Managenent Service, P.O. Box 7944, Metirie, IA 77010; And Was Wet E. Sweet, Mineral Management Service, P.O. Box 7944, Metairie, LA 77010; Andreas Wetzel, Geologisches Palaeontologisches Institut der Universităt, Sigwartstrasse 10, D7400 Tübingen, Federal Republic of Germany; and Jean K. Whelan, Chemistry Department, Woods Hole Oceanographic Institution, Woods Hole, MA 02543.
}

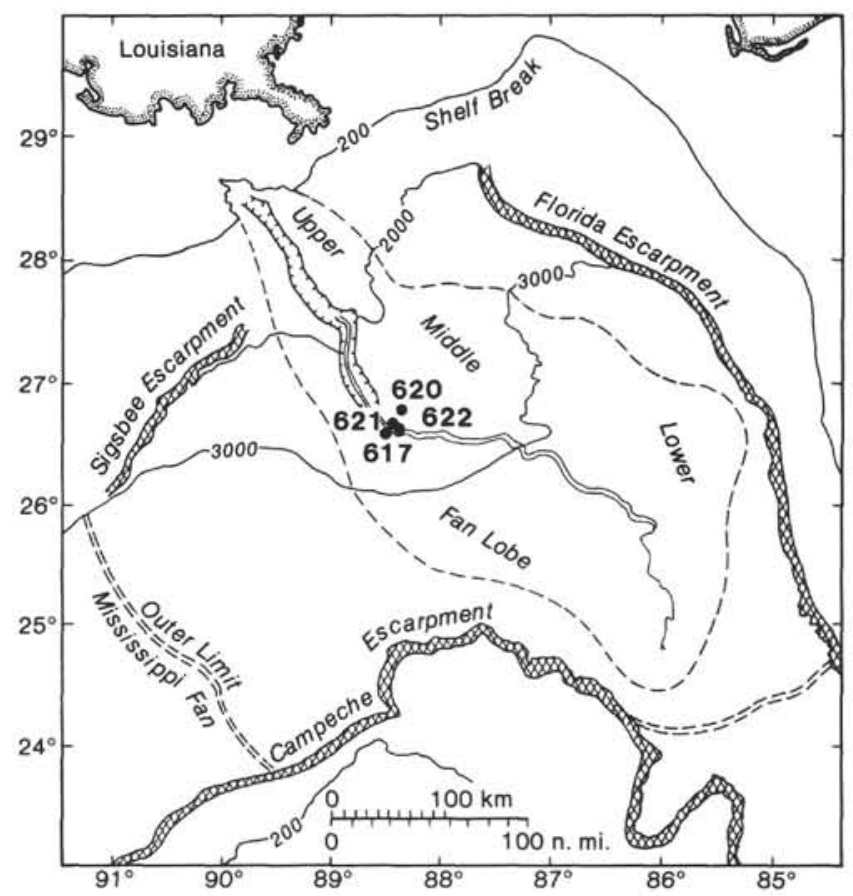

Figure 1. Generalized map of Mississippi Fan, with general outline of the modern fan lobe and midfan sites drilled during DSDP Leg 96.

penetration seismic reflection profiles reveals that this area contains a channel complex that is approximately 8 to $10 \mathrm{~km}$ wide and up to $200 \mathrm{~m}$ thick. This channel complex is flanked by laterally thinning overbank deposits.

Four site locations were selected to obtain maximum information about the types and distribution of the sediments and to answer a number of pertinent questions. Physiographically, the locations of these sites were

Site 621: outer convex meander bend (thalweg) of the present channel,

Site 622: inner concave meander bend ("point bar") of the present channel,

Site 617: overbank deposits immediately adjacent to the channel in the ridge and swale topography, and

Site 620: overbank deposits outside the channel-levee complex, approximately $18 \mathrm{~km}$ away from the channel.

The data from these borings could be used to identify the major stratigraphic and lithologic characteristics of each location. In addition, the data provided information about the spatial and temporal relationships for this part of the middle fan. These preliminary conclusions will be used to typify the entire middle fan.

In addition to the above-mentioned objectives, some specific goals were set that could be accomplished by studying the cores. The most important ones were to 


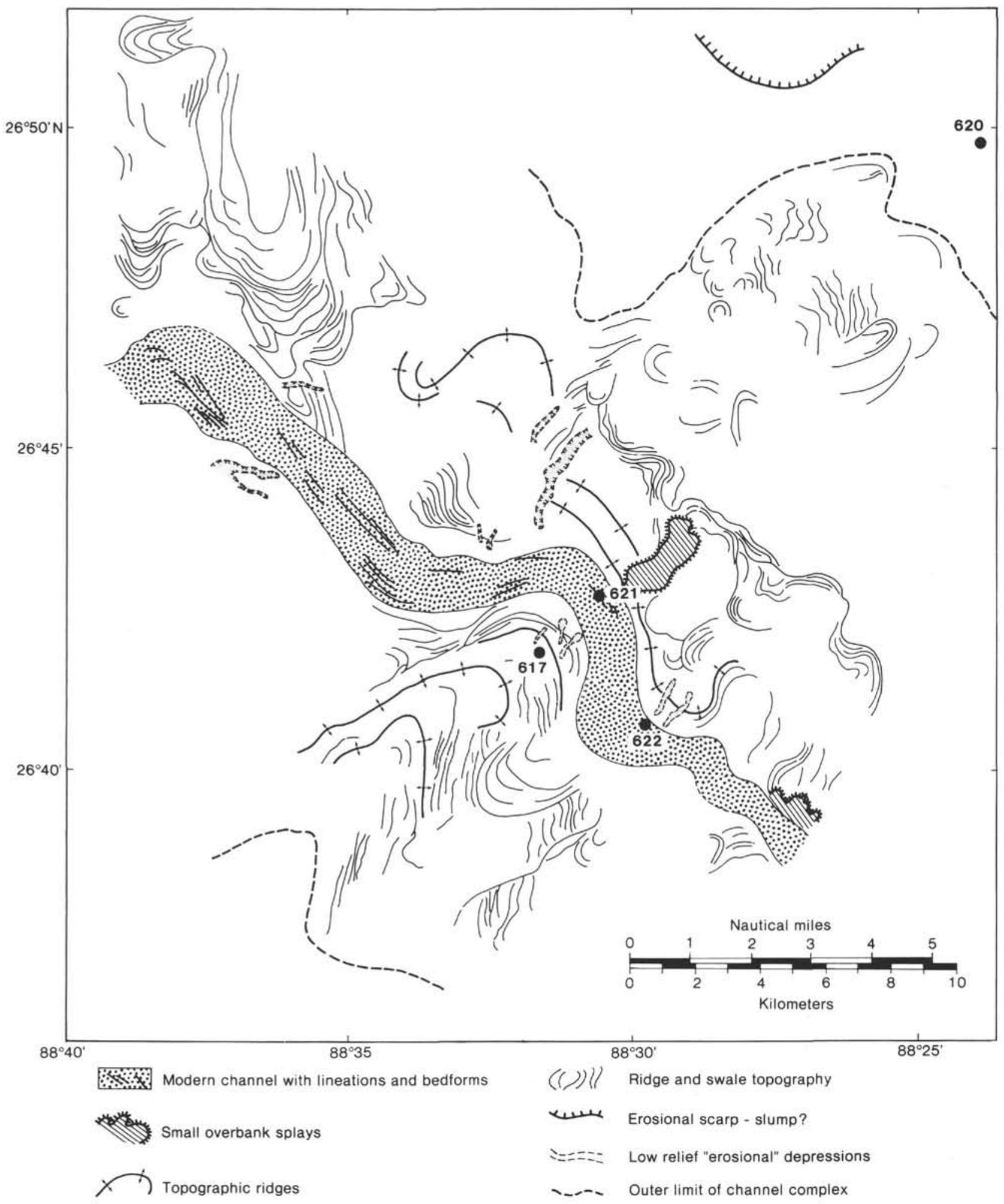

Figure 2. Generalized morphology of the middle fan based on interpretation of GLORIA, Sea MARC, and EDO side-scan sonar data. Locations of drill sites relative to morphology are indicated. 
1. Identify the lithologic nature of the acoustical reflectors, specifically that of the acoustically high-amplitude zone located at the base of the channel (Sites 621 and 622).

2. Obtain lithologic and time-stratigraphic data for the entire channel fill (Sites 621 and 622).

3. Determine if the sinuous character of the channel represents channel migration and aggradation (Sites 617, 621 , and 622).

4. Determine if fluvial-like processes were operative by comparing the two channel sites and their sediment types (Sites 621 and 622).

5. Identify the nature of the overbank deposits both adjacent to the channel and farther away. Determine whether these deposits are dominantly thin-bedded turbidites or are basically muds with few or no coarser beds (Sites 617 and 620).

6. Determine the rates of sedimentation for all sites and relate this to transport processes (Sites 617, 620, 621 , and 622).

7. Utilize the lithologic characteristics and the sedimentary structures to establish which sedimentary processes were operative in the middle fan area (Sites 617, 620,621 , and 622).

8. Compare the drilling results with information on ancient submarine fan deposits published in the geological literature and evaluate whether any of the published models are applicable.

9. Determine the degree of consolidation and analyze the relationship of geochemical parameters to the geotechnical properties.

\section{SUMMARY}

The drilling results for the four sites on the middle fan provided a great deal of information about the characteristics and properties of a submarine fan channeloverbank system. The following major conclusions can be drawn:

1. It can be demionstrated that the single sinuous channel has been migratory and aggradational in nature and that it has some general similarity to migratory fluvial systems. This is partly supported by the fining-upward sequence of the channel fill and the presence of a thicker sandy section in the lower part of the fill of the "point bar" area compared to the "thalweg" area. The basal gravelliferous and sandy sediments represent a channel lag deposit. These lag deposits are characterized by an acoustically high-amplitude zone that is about three times the actual channel width and climbs stratigraphically upward while migrating laterally.

2. Comparing the fining-upward channel fill with the generally fine-grained overbank deposits reveals that the channel acted primarily as a conduit and that it confined the transported coarser-grained materials within and below its levees while only finer-grained sediments escaped these confines in large quantities to form the overbank deposits. The number of thin-bedded turbidites expected in the overbank facies proved to be very small; the area immediately adjacent to the channel contains a greater number of these thin-bedded turbidites than the more marginal area.

3. The channel fill is characterized by a lack of indigenous fauna and contains only a sparse, reworked outer neritic and upper slope microfauna. The cores collected from the middle fan area only represent deposition during the late Wisconsin.

4. The Mississippi Fan is considered to be a predominantly fine-grained depositional system. The drilling demonstrated that extremely coarse sediment can be transported over long distances $(>300 \mathrm{~km})$ within the confines of a channel that has a very low gradient.

5. Sedimentation rates in the middle fan area are extremely high, both for the entire channel fill and for the overbank areas. A minor decrease in sedimentation rate was found toward the fan lobe margins. This implies that large amounts of fine-grained sediment were transported and that overall sedimentation, especially for the clayey deposits, was nearly constant in a geological sense. The sedimentary structures and position of some of the microfauna, observed in X-ray radiographs, show that fluctuations in intensity of deposition were common. 